\title{
Geochronology of the Letete and Waweig formations, Mascarene Group, southwestern New Brunswick
}

\author{
B.V. Miller ${ }^{1}$ AND L.R. FyfFE ${ }^{2}$ \\ 1. Department of Geology, University of North Carolina, Chapel Hill, North Carolina, 27599-3315, USA \\ 2. New Brunswick Department of Natural Resources and Energy, Geological Surveys Branch, \\ P.O. Box 6000, Fredericton, New Brunswick E3B 5H1,Canada \\ Date received:September 25, 2002 Date accepted:December 2, 2002
}

\begin{abstract}
Felsic tuffs from the Letete and Waweig formations of the Mascarene Group in southwestern New Brunswick have essentially identical U-Pb ages of $437 \pm 7$ and $438 \pm 4 \mathrm{Ma}$ and were, therefore, both deposited in the Llandoverian of the Early Silurian. These radiometrically determined ages bring into question the validity of assigning Late Silurian ages to rock units in the Mascarene Basin based on the presence of Salopina sp. The new data also indicate that rate of deposition for the volcanic sequences in the Mascarene Basin of New Brunswick is similar to that of the classic sections in coastal Maine.
\end{abstract}

\section{RESUMÉ}

\begin{abstract}
Les tufs felsiques des formations de Letete et de Waweig du groupe de Mascarene dans le Sud-Ouest du Nouveau-Brunswick ont des âges au U-Pb essentiellement identiques de $437 \pm 7$ et $438 \pm 4 \mathrm{Ma}$; ils se sont par conséquent déposés dans les deux cas au cours du Valentien, pendant le Silurien précoce. Ces âges radiométriques remettent en question la validité de l'attribution d'âges remontant au Silurien tardif aux unités rocheuses du bassin de Mascarene basée sur la présence de l'espèce Salopina. Les nouvelles données révèlent par ailleurs que le rythme de sédimentation des séquences volcaniques dans le bassin de Mascarene au Nouveau-Brunswick est semblable à celui des sections classiques le long du littoral du Maine.
\end{abstract}

\section{INTRODUCTION}

Late Ordovician to Early Devonian sedimentary and volcanic strata included in the Mascarene Group of southwestern New Brunswick are distributed along the boundary between Precambrian peri-Gondwanan basement to the southeast and a thick succession of Early to Middle Ordovician sedimentary rocks to the northwest. Several transcurrent faults transect this boundary zone, so that the strata of the Mascarene Group now occupy several fault-bounded blocks (Fig. 1). Similar faunal assemblages (Boucot et al. 1966; Watkins and Boucot 1975) suggest these blocks were once part of a composite marine depocentre, referred to as the Mascarene Basin by Fyffe et al. (1999). However, paleontological control is insufficient to make reliable chronostratigraphic correlations among the fault-blocks. In addition, the possibility of making regional lithostratigraphic correlations is limited by rapid facies variations that are to be expected in such complex volcanic environments.

In order to clarify the age relationships throughout the Mascarene Basin, samples of felsic volcanic rocks for geochronological analyses were collected from northwest and southeast of the St. George Fault (Fig. 1). This fault divides the Mascarene Basin into two domains that possess distinctive stratigraphies and structural styles. Deformation is much more intense to the southeast of the fault, where multiphase folding and shear-related fabrics have strongly modified primary layering. The stratigraphic succes- sions in the two regions are outlined below, followed by description of the samples and their positions within these successions. Results of the radiometric analyses have enabled correlations to be made between the northwestern and southeastern parts of the Mascarene Basin in New Brunswick and with the classic succession in coastal Maine (Gates 1975; 1977).

\section{STRATIGRAPHY NORTHWEST OF THE ST. GEORGE FAULT}

Silurian strata underlying the Mascarene Basin on the northwestern side of the Saint George Batholith appear to form a continuous, homoclinal sequence facing to the southeast (Fyffe et al. 1999). Bedding attitudes in the Early Devonian strata on the southeastern side of Saint George Batholith are significantly shallower but continue to dip and face to the southeast as far as the St. George Fault (Fig. 1). However, it cannot be ascertained that the entire Mascarene succession to the northwest of the St. George Fault is a continuous southeasterly younging section, as the emplacement of the Saint George Batholith may have obscured the presence of a major fault.

The northwestern margin of the Mascarene Basin in this region is defined by the Sawyer Brook Fault, which separates the Oak Bay Formation, a $600 \mathrm{~m}$-thick sequence of polymictic conglomerate and sandstone, from Early Ordovician black shale of the Cookson 


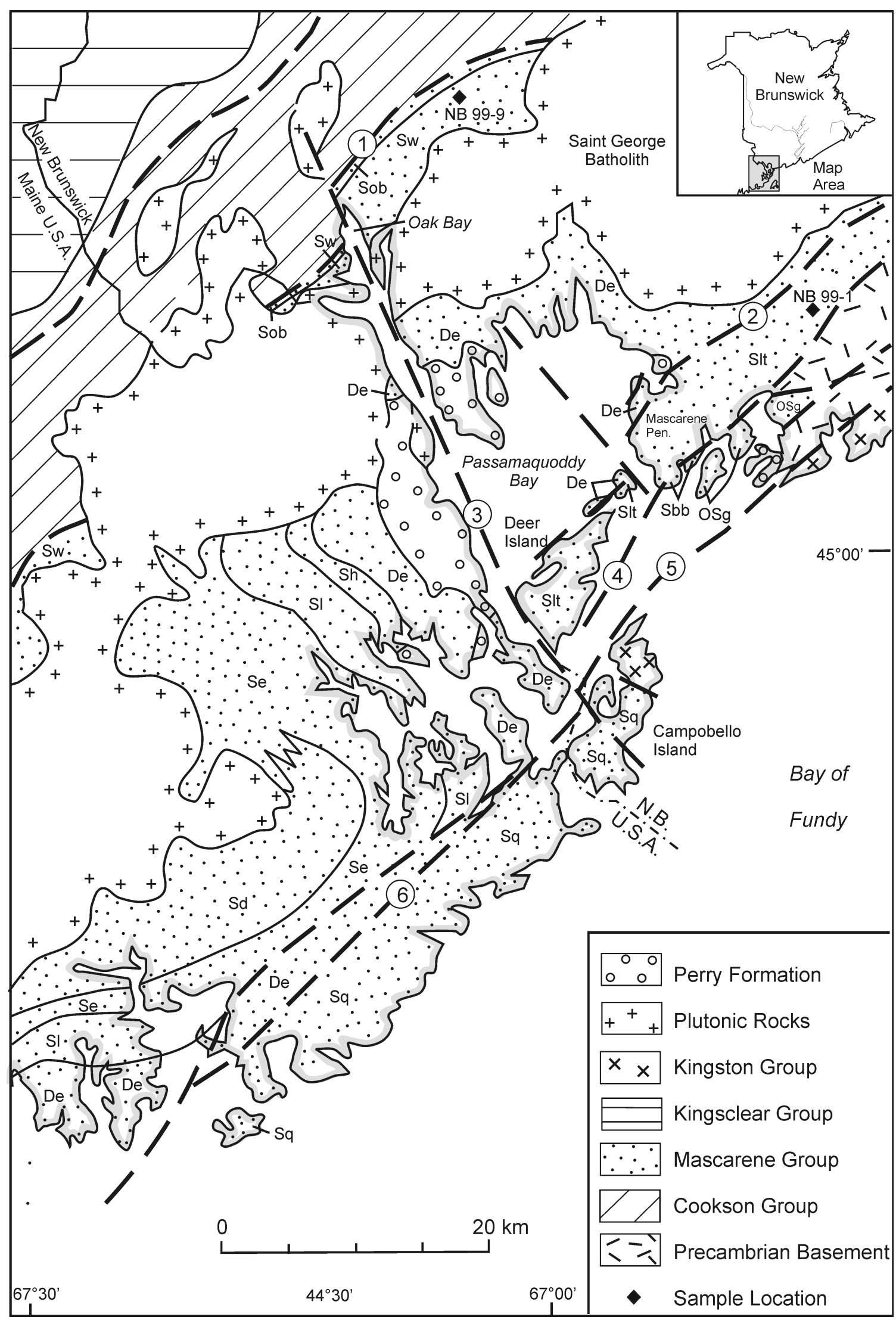


Group (Fig. 1). A pentameroid brachiopod in a limestone clast from conglomerate on Cookson Island in Oak Bay reportedly indicates that the Oak Bay Formation is no older than Llandoverian, although it could be significantly younger (Cumming 1966).

The conformably overlying Silurian Waweig Formation comprises approximately $4200 \mathrm{~m}$ of volcanic and resedimented volcaniclastic and siliciclastic sandstone and mudstone dipping moderately and uniformly to the southeast away from the Oak Bay conglomerate. Fyffe et al. (1999) subdivided the Waweig Formation into three members: a lower volcaniclastic- and felsic volcanic-dominated Campbell Point Member ( $600 \mathrm{~m}$ thick); a medial grey to black shale-and mafic volcanic-dominated Sawyer Brook Member ( 300-600 m thick); and an upper siliciclasticdominated Simpson Corner Member with minor associated volcanic rocks ( 3000 $\mathrm{m}$ thick).

Differing opinions have been offered on whether the depositional range of the Waweig Formation spanned most of the Silurian or was restricted to the latest Silurian (Cumming 1966; Ruitenberg 1967, 1968; Pickerill 1976). The brachiopod Salopina submedia has been reported from various locations within the Simpson Corner Member of the Waweig Formation in southwestern New Brunswick (Cumming 1966; Pickerill 1976; Fyffe et al. 1999). In adjacent Maine, Salopina submedia is found in association with Pridolian ostracodes in grey shale of the Leighton Formation (Berdan 1971). Pickerill (1976) suggested, by comparison to the Maine section, that the Waweig Formation is also likely of latest Ludlovian to Pridolian age, although Salopina, by itself, is not definitive of a Late Silurian age. For example, Salopina submedia occurs in beds as old as latest Llandoverian to Wenlockian in the Arisaig Group of Nova Scotia (Harper 1973). Furthermore, the great thickness of the Waweig Formation and relatively short duration of the Pridolian (see Tucker and McKerrow 1995) would also call the paleontological evidence into question.

The composite Late Silurian to Late Devonian Saint George Batholith (McLeod 1990) separates the Waweig Formation from a distinctive, gently-dipping, shallow-water sequence exposed to the southeast along Passamaquoddy Bay. Pickerill and Pajari (1976) correlated these intertidal to fluvial sedimentary and associated volcanic rocks with the Eastport Formation of coastal Maine. The Eastport Formation in New Brunswick comprises amygdaloidal mafic flows and agglomerate, massive to flow-banded felsic flows, welded and non-welded lapilli tuff, pisolitic tuff, peperitic breccia, and grey to maroon sandstone and conglomerate totalling $\sim 4000 \mathrm{~m}$ (Hay 1967; Pickerill and Pajari 1976; Pickerill et al. 1978; Van Wagoner et al. 1988, 1994; Dadd and Van Wagoner 2001). Ostracodes from both the Hersey and the Eastport formations of coastal Maine are indicative of an Early Devonian age (Berdan

FIG.1 (Facing page) Geotectonic map of southwestern New Brunswick and adjacent Maine. Formations of the Mascarene Group: OSg = Goss Point, $S q=$ Quoddy, Sbb = Back Bay, Sd = Dennys, $S e=E d m u n d s, S h=$ Hersey, Sl $=$ Leighton, Slt $=$ Letete, Sob $=$ Oak Bay, Sw = Waweig, De =Eastport. Faults: $(1)=$ Sawyer Brook, (2) =St. George, (3)= Oak Bay, (4) = Back Bay, (5)=Beaver Harbour-Belleisle, (6) = Lubec. Modified after Fyffe et al. (1999).
1971). Late Devonian conglomerate of the Perry Formation lies unconformably on the Eastport Formation (Fig. 1).

\section{STRATIGRAPHY SOUTHEAST OF THE ST. GEORGE FAULT}

The southeastern parts of the Mascarene Basin comprise a series of narrow fault blocks of Precambrian basement, commonly separated by slices of Paleozoic strata. The St. George, Back Bay, Beaver Harbour-Belleisle, and Lubec faults define the boundaries of these highly sheared blocks (Fig. 1).

The St. George Fault (Fig. 1), which separates gently dipping beds of the Eastport Formation along the northern shore of Passamaquoddy Bay from polydeformed sandstone, shale, and felsic and mafic lithic tuffs and flows of the Letete Formation on the Mascarene Peninsula, defines the northwestern margin of this highly disrupted zone in New Brunswick. Although a number of lithotypes have been delineated within the Letete Formation, the stratigraphic relationship among them remains uncertain because of complex deformation (DeCarle 1966; Ruitenburg 1968; Donohoe 1973, 1978). Brachiopod genera found in the Letete Formation near the Deer Island ferry landing on the Mascarene Peninsula include Howellella ? sp., which indicates an age no older than late Llandoverian, and Salopina sp., which has been used to suggest a Late Silurian age for the Letete Formation (Donohoe 1978).

Paleozoic strata of the Mascarene Group in the tectonic sliver between the Back Bay and Beaver Harbour-Belleisle faults (Fig. 1) are included in the Goss Point and Back Bay formations (Donohoe 1973, 1978; McLeod 1995; Johnson and McLeod 1996). Limestone associated with quartzose sandstone in the lower part of the Goss Point Formation contains a conodont assemblage dated as Late Ordovician (late Caradocian to Ashgillian) (Nowlan et al. 1997). The upper part of the Goss Point Formation comprises felsic tuff and agglomerate, locally containing clasts of limestone, and minor mafic flows (Donohoe 1973, 1978). A small sliver in this block contains Silurian shallow-water sandstone and felsic tuff of the Back Bay Formation of probable late Llandoverian age on the basis of Pentamerus sp. (Boucot et al. 1966; Donohoe 1973, 1978).

The block to the southeast of the Lubec Fault (Fig. 1), in coastal Maine, is underlain by pyritic black shale and laminated mudstone, pillow lava and breccia, and minor felsic flows and tuff of the Quoddy Formation (Gates 1961, 1969, 1977). A late Llandoverian age is indicated by graptolites in the shale, and the brachiopod Stricklandia lens ultima in limestone fragments enclosed in the mafic breccia (Gates 1961; Boucot et al. 1966). The Quoddy Formation is intruded by abundant mafic dykes referred to by Gates (1961) as the Cutler Diabase. The Quoddy Formation extends northeastward onto Campobello Island in New Brunswick (Fig. 1), where it contains an abundance of thickbedded, turbiditic sandstone in a section that is at least $1500 \mathrm{~m}$ thick (McLeod and Rast 1988; McLeod et al. 2001).

A belt of Silurian felsic lithic and crystal tuffs, mafic flows and tuffs, and tuffaceous siltstone to the southeast of the Beaver 
Harbour-Belleisle Fault (Fig. 1) are included in the Kingston Group (Barr and White 2001). These rocks can be traced from Campobello Island in the Bay of Fundy for over $100 \mathrm{~km}$ along strike to the northeast as far as the Kingston Peninsula (Barr and White 2001; McLeod et al. 2001; Barr et al. 2002). U-Pb dating of zircons from felsic volcanic rocks of the Kingston Group have yielded Llandoverian ages ca. $438 \mathrm{Ma}$ (Barr et al. 1997; Miller et al. 2000; Barr et al. 2002).

\section{GEOCHRONOLOGY}

Samples of felsic volcanic rocks for geochronological analyses were chosen from opposite sides of the St. George Fault in order to investigate the age relationships between these disparate parts of the Mascarene Basin. Analytical techniques follow those described in Ratajeski et al. (2001). All data are reported at the two-sigma level.

The first site is located $15 \mathrm{~km}$ inland of the Mascarene Peninsula at a distance of about three kilometres to the southeast of the St. George Fault and one kilometre to the northwest of the Back Bay Fault (Fig. 1). Felsic tuff of the Letete Formation (sample NB99-1) was collected at this site from an outcrop on a hillside (lat. $45^{\circ} 09^{\prime}$ $44^{\prime \prime}$; long. $66^{\circ} 43^{\prime} 50^{\prime \prime}$ ) behind a landfill site located $400 \mathrm{~m}$ northwest of the Spear Road at a distance of $1.5 \mathrm{~km}$ northeast of Utopia Centre in Charlotte County (see Plate 98-70; Fyffe 1998). The sampled horizon is a massive, dark grey, fine-grained, crystal tuff that is interbedded with coarse, lithic tuff containing mafic and felsic fragments. Its exact stratigraphic position within the highly deformed and fault-bounded section of the Letete Formation is not known. A fossil locality in calcareous sandstone, about six kilometres northeasterly along trend of the sample site, includes the brachiopods Isorthis sp., Meristina sp., Atrypa "reticularis" sp., Dalejina sp., Nucleospira sp., and Resserella sp. indicative of a Late Llandoverian to Ludlovian age (Boucot, written communication to Susan Johnson, 1992; Johnson and McLeod 1996).

Seven zircon U-Pb analyses from sample NB99-1 consist of four single-grain and three multi-grain fractions (Table 1). Very low $U$ and radiogenic $\mathrm{Pb}$ concentrations characterize all fractions. Six of the seven analyses lie on a well-defined discordia line with an upper intercept of $437 \pm 7 \mathrm{Ma}$ and a lower intercept suggestive of recent Pb-loss (Fig. 2). One single-grain analysis falls distinctly off the discordia trend because of a component of inheritance. We interpret the upper intercept age to be the best estimate for the time of deposition of the Letete Formation felsic tuff.

The second site selected for geochronological study is located about 30 kilometres to the northwest of the St. George Fault in the Oak Bay area of Charlotte County (Fig. 1). Felsic crystal tuff within the Campbell Point Member of the Waweig Formation (sample NB99-9) was collected from an outcrop on the west side of Route 127 (lat. $45^{\circ} 17^{\prime} 30^{\prime \prime}$; long. $\left.67^{\circ} 07^{\prime} 11^{\prime \prime}\right)$, about $150 \mathrm{~m}$ south of the Sawyer Road intersection (see Plate 97-5; Fyffe 1997). The tuff horizon is several metres thick and is overlain and underlain by fine-grained sandstone about $800 \mathrm{~m}$ above the contact with conglomeritic beds of the stratigraphically underlying Oak Bay Formation. It should be noted that Salopina sp. has been reported
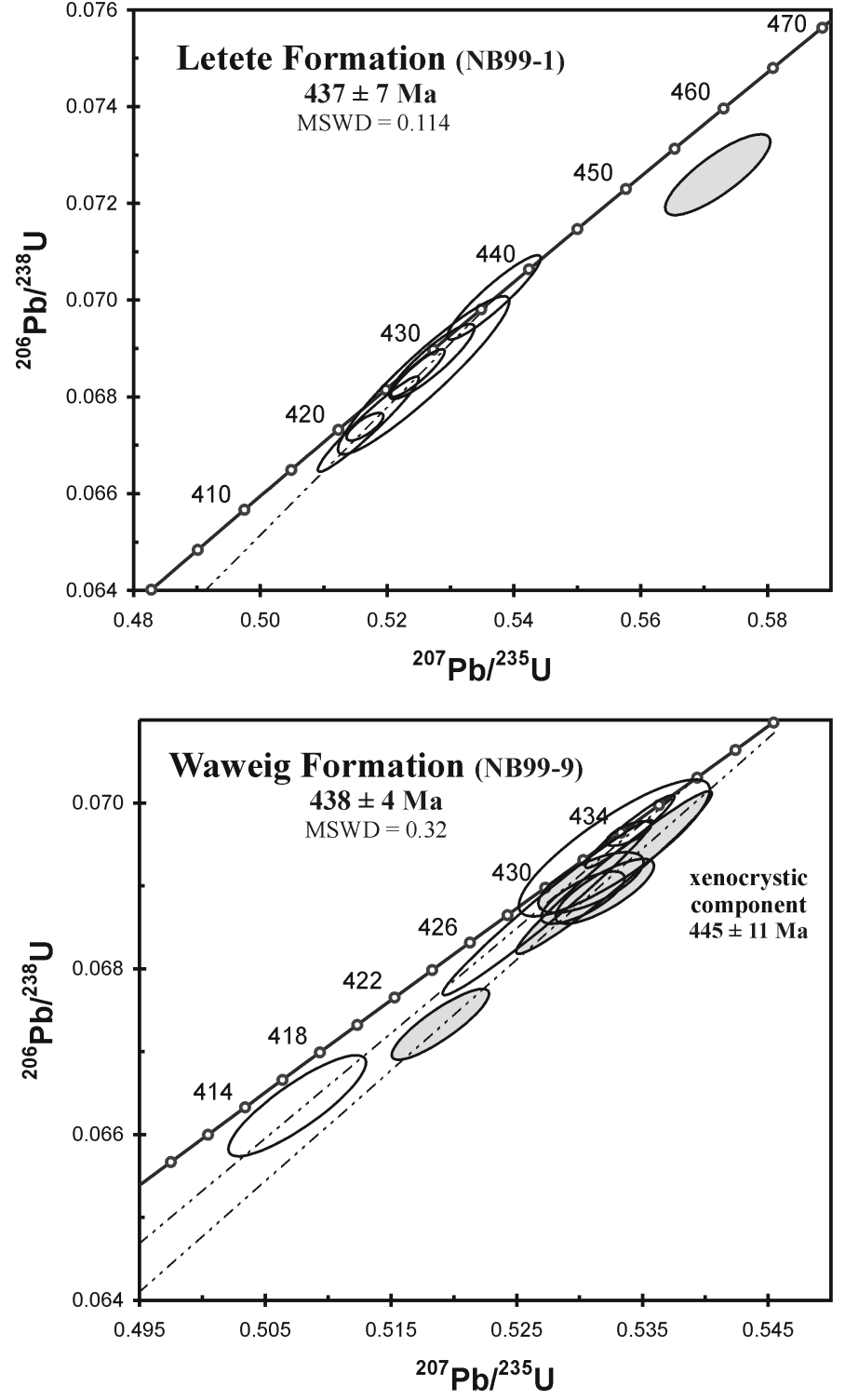

FIG. 2 Concordia diagrams for the Letete and Waweig felsic tuffs. Shaded error ellipses denote fractions with inheritance. Sample locations are shown in Fig. 1.

from mafic hyaloclastite beds of the Sawyer Brook Member about $200 \mathrm{~m}$ stratigraphically above the sampled Campbell Point tuff horizon (Fyffe et al. 1999).

Ten zircon fractions from sample NB99-9 include three single-grain fractions (Table 1). Five fractions with ${ }^{207} \mathrm{~Pb} /{ }^{206} \mathrm{~Pb}$ ages between 432 and 439 Ma form a discordant trend anchored by two high-precision concordant points and one relatively lowerprecision concordant point (Fig. 2). Regression of these five analyses yields an upper intercept of $438 \pm 4 \mathrm{Ma}$, which we interpret to be the time of deposition of the Waweig Formation felsic tuff. The remaining five fractions lie only very slightly to the right of the discordant magmatic trend with ${ }^{207} \mathrm{~Pb} /{ }^{206} \mathrm{~Pb}$ ages between 443 and $452 \mathrm{Ma}$. We interpret these latter five analyses to contain a component of only slightly older inherited zircon. Some degree of mixing between the ca. $438 \mathrm{Ma}$ (magmatic) zircon and the slightly 


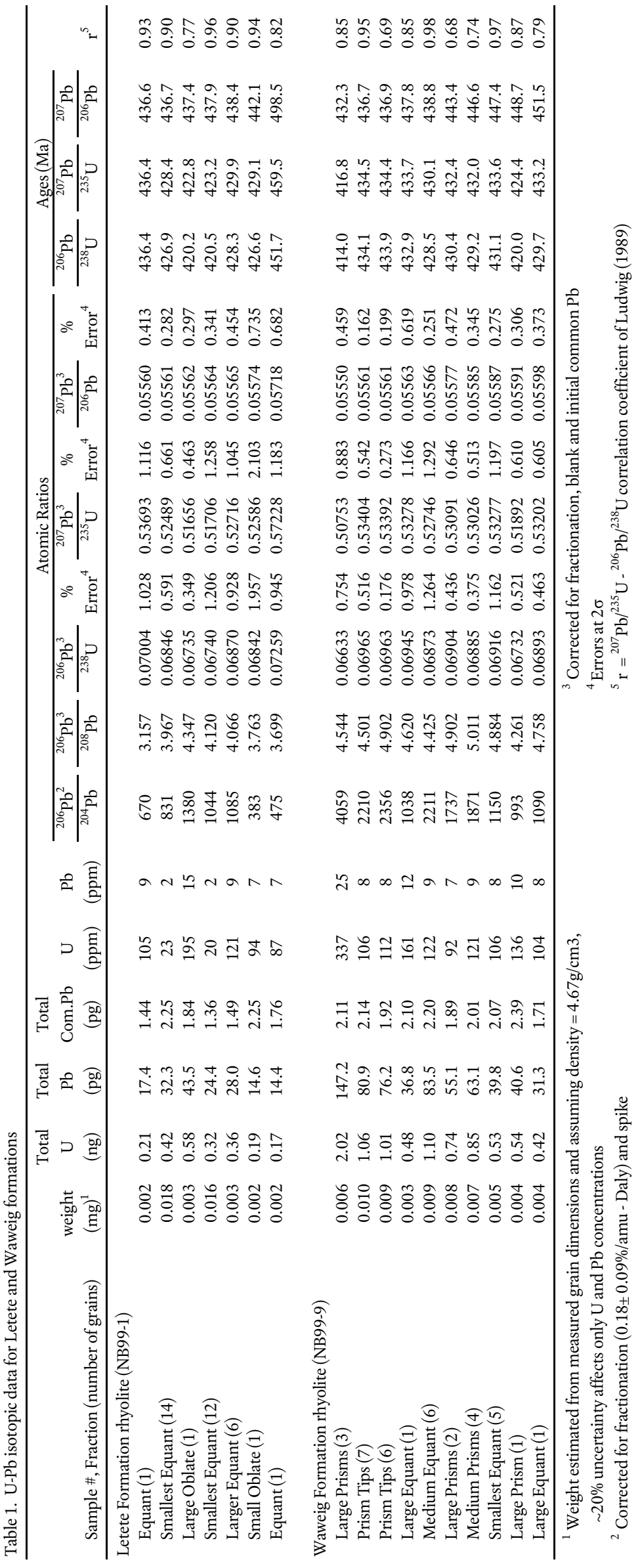




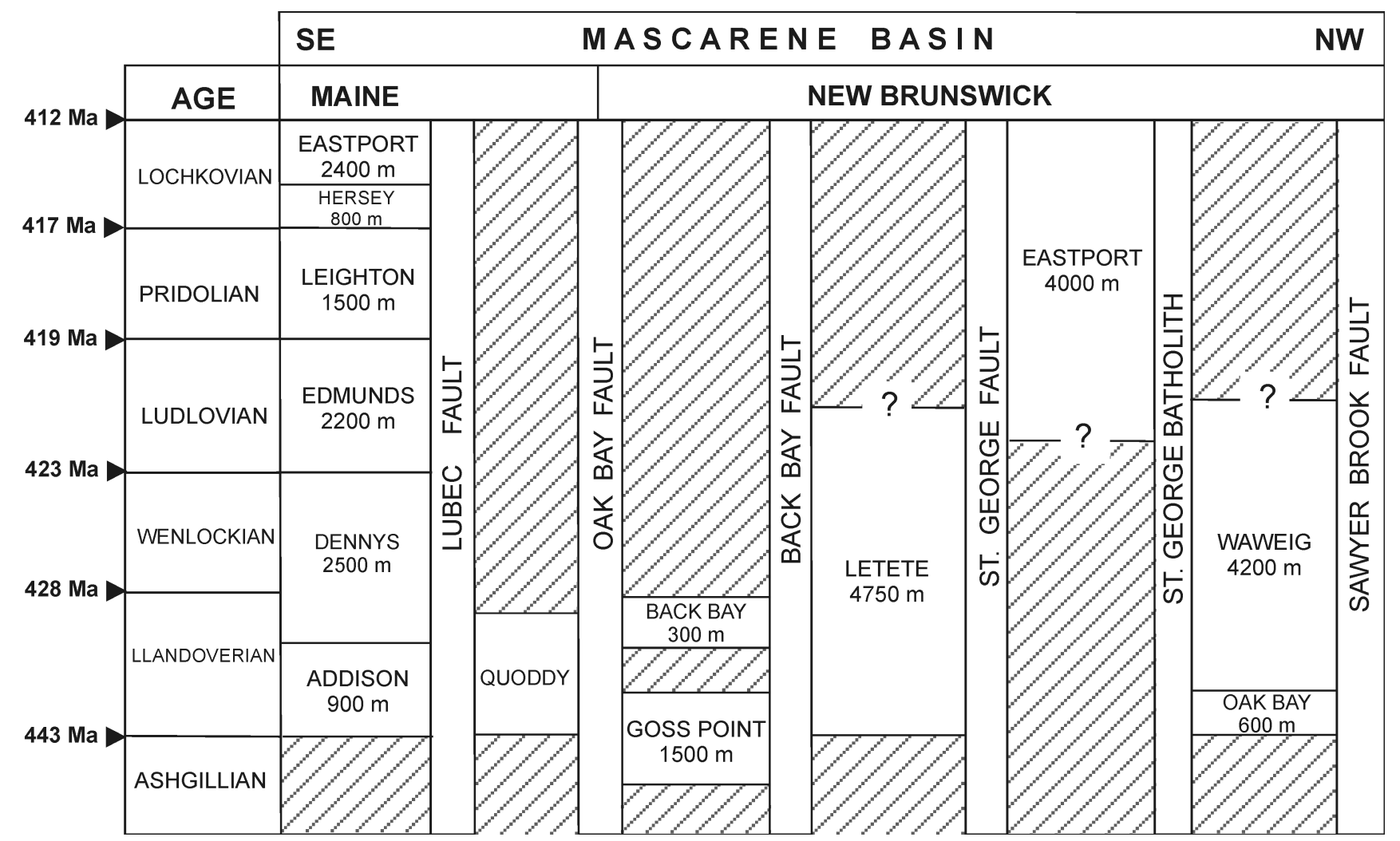

FIG. 3 Correlation chart showing stratigraphic ranges and estimated thicknesses for formations comprising the Mascarene Basin. Absolute ages for stage boundaries are from Tucker and McKerrow (1995).

older inherited component is likely and because error ellipses overlap this makes a clearer separation of the two components difficult. Regression of these five points suggests that the inherited component is likely not older than $445 \pm 11 \mathrm{Ma}$, within the error of the inferred magmatic age.

\section{DISCUSSION AND CONCLUSIONS}

The felsic tuffs from the Letete and Waweig formations of the Mascarene Group have essentially identical U-Pb ages of $437 \pm 7$ $\mathrm{Ma}$ and $438 \pm 4 \mathrm{Ma}$, respectively (Fig. 2). According to the timescale of Tucker and McKerrow (1995), these tuffs were deposited during the Llandoverian stage of the Early Silurian. The age determinations, therefore, indicate that both the homoclinal Oak Bay-Waweig sequence and the highly deformed Letete sequence, located on opposite sides of the St. George Fault, are significantly older than previously assumed.

The lower part of the Waweig Formation is now proven to extend well down into the Early Silurian as demonstrated by the Llandoverian age obtained from the Campbell Point Member. Moreover, a Late Silurian age of $418 \pm 5$ Ma for the older portion of the cross-cutting Saint George Batholith (McLeod 1990) indicates that the Simpsons Corner Member in the upper part of the Waweig Formation is likely no younger than Ludlovian. Thus the latest Ludlovian-Pridolian age previously assigned to these rocks based on extrapolated paleontological criteria from coastal Maine (Pickerill 1976) cannot be maintained.

The Waweig Formation must now be considered to have been deposited over approximately the same time span as the Dennys and Edmunds formations in Maine (Fig. 3). The similar thicknesses of $4200 \mathrm{~m}$ for the Waweig Formation and $4700 \mathrm{~m}$ for the combined Dennys and Edmunds formations (Gates 1975; 1977; Fyffe et al. 1999) are consistent with similar rates of deposition during this period of time. However, the Waweig Formation differs lithologically from its chronological equivalents in Maine by containing a higher proportion of sedimentary to volcanic rocks, perhaps as a result of deposition more distal from volcanic edifices. The Addison conglomerate with a thickness of $900 \mathrm{~m}$ (Gates 1989) at the base of the Silurian sequence in coastal Maine, and conglomerate of the Oak Bay Formation with a thickness of $600 \mathrm{~m}$ beneath the Waweig Formation in New Brunswick may represent contemporaneous debris flows marking the initiation of rifting along the northwestern part of the Mascarene Basin.

A much shallower water to subaerial volcanic and sedimentary sequence occurs within the Mascarene Basin of New Brunswick between the Saint George Batholith to the northwest and the Saint George Fault to the southeast. These strata have previously been correlated with the entire coastal section of Maine (Hay 1967), or alternatively only to the Eastport Formation at the top of the Maine section (Pickerill and Pajari 1976). The latter interpretation has been used on the construction of Fig. 1. However, U-Pb dat- 
ing of a felsic tuff from this section in New Brunswick has yielded a latest Wenlockian to earliest Ludlovian age of $423 \pm 1 \mathrm{Ma}$ (Dadd and Van Wagoner 2001) so that part of this sequence is apparently as old as the Edmunds Formation of Maine (Fig. 3). Nonetheless, sedimentological characteristics in the New Brunswick section more closely resemble those of the younger Leighton through Eastport formations of Maine. Either a significant facies change has occurred across the region or possibly the base of the Leighton Formation in Maine is older than Pridolian, its accepted age on the basis of paleontological evidence (Berdan 1971).

The radiometrically determined Llandoverian age for the Letete Formation reported in this study further brings into question the validity of assigning Pridolian ages to rock units in the Mascarene Basin based on the presence of Salopina sp. Its estimated thickness of $4750 \mathrm{~m}$ is very close to that of the combined Dennys and Edmunds formations in Maine so that the Letete Formation could possibly be in part as young as Ludlovian. Bounded by the St. George and Back Bay faults, the complexly deformed Letete Formation represents a tectonic entity that appears lithologically distinct from other parts of the Mascarene Basin. However, comparisons to the Quoddy Formation of Campobello Island and coastal Maine have been made by Hay (1967) and Ruitenberg (1968) based largely on the presence of black shale. Such a correlation would be more tenable if a Llandoverian age were to be substantiated for the entire Letete section. The Letete and Quoddy formations could then be interpreted to represent contemporaneous facies of the deep Early Silurian parts of the Mascarene Basin. This deepening of the basin may be reflected in the Waweig Formation to the northwest of the St. George Fault by the black shale and mafic tuff of the Sawyer Brook Member since these strata immediately overlie the dated Early Silurian felsic tuff of the Campbell Point Member (Fyffe et al. 1999). Additional radiometric dating is in progress on volcanic rocks of the Letete Formation (Malcolm McLeod, personal communication, 2002), that will more fully establish their depositional timeframe and, thereby, lead to a better understanding of the tectonic evolution of the Mascarene Basin.

\section{ACKNOWLEDGEMENTS}

The results presented here are part of a collaborative radiometric dating program undertaken with Sandra Barr of Acadia University on Silurian volcanic rocks in southern New Brunswick. We thank Tovah Bayer for help in sample preparation and Rhonda Doiron for preparing the figures. Critical reviews by Chris White and Sue Johnson are greatly appreciated.

\section{REFERENCES}

Barr, S.M. And White, C.E. 2001. The Kingston Group: a redefined Silurian stratigraphic unit in southern New Brunswick. In Current Research 2000. Compiled by B.M.W. Carroll. New Brunswick Department of Natural Resources and Energy,
Minerals and Energy Division, Mineral Resource Report 20014, pp. 1-14.

Barr, S.M., White, C.E., And McLeod, M.J. 1997. Geology of the Kingston Peninsula, southern New Brunswick: a preliminary report. In Current Research 1996. Edited by B.M.W. Carroll. New Brunswick Department of Natural Resources and Energy, Minerals and Energy Division, Mineral Resource Report 97-4, pp. 1-20.

Barr, S.M., White, C.E., ANd Miller, B.V. 2002. The Kingston terrane, southern New Brunswick, Canada: Evidence for an Early Silurian volcanic arc. Geological Society of America Bulletin, 114, pp. 964-982.

BERDAN, J.M. 1971. Silurian to Early Devonian ostracodes of European aspect from the Eastport Quadrangle, Maine. Geological Society of America, Abstracts with Programs, 3, No. 1, p. 18.

Boucot, A.J., Johnson, J.G., Harper, C., and Walmsley, V.G. 1966. Silurian brachiopods and gastropods of southern New Brunswick. Geological Survey of Canada, Bulletin 140, $45 \mathrm{p}$.

Cumming, L.M. 1966. Geology of the Passamaquoddy Bay region, Charlotte County, New Brunswick. Geological Survey of Canada, Paper 65-29, 36 p.

Dadd, K. A. AND Van Wagoner, N.A. 2001. Physical volcanology of the Silurian CVB rocks of Passamaquoddy Bay, southwestern New Brunswick. In Guidebook to Field Trips in New Brunswick and Eastern Maine. Edited by R.K. Pickerill and D.R. Lentz. New England Intercollegiate Geological Conference, Fredericton, New Brunswick, pp. C2-1 to C2-13.

DeCarle, A.L. 1966. Letete-Mascarene Peninsula. In Geological Investigations in New Brunswick, J.C. Smith (editor). New Brunswick Department of Lands and Mines, Mines Branch, Information Circular 66-1, pp. 9-14.

Donohoe, H.V., Jr. 1973. Acadian orogeny in coastal New Brunswick. In Geology of New Brunswick. Edited by N. Rast. New England Intercollegiate Geological Conference, Field Guide to Excursions, pp. 71-80.

Donohoz, H.V., JR. 1978. Analysis of structures in the St. George area, Charlotte County, New Brunswick. Unpublished Ph.D. thesis, University of New Brunswick, Fredericton, New Brunswick, $227 \mathrm{p}$.

FyfFE, L.R. 1997. Geology of the Sorrel Ridge area (NTS 21/G6a), Charlotte County, New Brunswick. New Brunswick Department of Natural Resources, Minerals and Energy Division, Plate 97-5.

FyFFE, L.R. 1998. Geology of the Jake Lee Mountain area (NTS 21/G2g), Charlotte County, New Brunswick. New Brunswick Department of Natural Resources, Minerals and Energy Division, Plate 98-70.

FyfFe, L.R., Pickerill, R.K., AND StRINGER, P. 1999. Stratigraphy, sedimentology, and structure of the Oak Bay and Waweig formations, Mascarene Basin: implications for the paleotectonic evolution of southwestern New Brunswick. Atlantic Geology, 35, pp. 59-84.

Gates, O. 1961. The geology of the Cutler and Moose River 
quadrangles, Washington County, Maine. Maine Geological Survey, Quadrangle Mapping Series No. 1, 67 p.

Gates, O. 1969. Lower Silurian-Lower Devonian volcanic rocks of New England coast and southern New Brunswick. In North Atlantic - Geology and Continental Drift. Edited by M. Kay. American Association of Petroleum Geologists, Memoir 12, pp. 484-503.

Gates, O. 1975. Geologic map and cross sections of the Eastport Quadrangle, Maine. Maine Geological Survey, Geological Map Series GM-3.

Gates, O. 1977. Notes to accompany Geological Map Series GM3, Washington County, Maine Geological Survey, $19 \mathrm{p}$.

Gates, O. 1989. Silurian roundstone conglomerates of coastal Maine and adjacent New Brunswick. In Studies in Maine Geology, Volume 2: Structure and Stratigraphy. Edited by R.D. Tucker and R.G. Marvinney. Maine Geological Survey, pp. 127-144.

Harper, C.W., Jr. 1973. Brachiopods of the Arisaig Group (Silurian-Lower Devonian) of Nova Scotia. Geological Survey of Canada, Bulletin 215, $163 \mathrm{p}$.

HaY, P.W. 1967. Sedimentary and volcanic rocks of the St. Andrews-St. George area, Charlotte County, New Brunswick. Department of Natural Resources, Mineral Resources Branch, New Brunswick, Map Series 67-1, 19 p.

Johnson, S.C. And MCLeod, M.J. 1996. The New River Belt: a unique segment along the western margin of the Avalon composite terrane, southern New Brunswick, Canada. In Avalonian and Related Peri-Gondwanan Terranes of the Circum-North Atlantic. Edited by R.D. Nance and M.D. Thompson. Geological Society of America, Special Paper 304, pp. 149-164.

LUDWIG, K.R. 1989. Pb-Dat: A computer program for processing raw $\mathrm{Pb}$-U-Th isotope data. United States Geological Survey, Open File Report 88-557, 34 p.

McLeod, M.J. 1990. Geology, geochemistry, and related mineral deposits of the Saint George Batholith; Charlotte, Queens, and Kings counties, New Brunswick. New Brunswick Department of Natural Resources and Energy, Mineral Resource Report 5, $169 \mathrm{p}$.

McLeod, M.J. 1995. Bedrock geology and metallic mineral occurrences in the Letang-Head Harbour Passage area, Charlotte County, New Brunswick. In Current Research 1994. Compiled and edited by S.A.A. Merlini. New Brunswick Department of Natural Resources and Energy, Minerals and Energy Division, Miscellaneous Report 18, pp. 141-156.

McLeod, M.J. AND Rast, N. 1988. Correlations and fault systematics in the Passamaquoddy Bay area, southwestern New Brunswick. Maritime Sediments and Atlantic Geology, 24, pp. 289-300.

McLeod, M.J., Pickerill, R.K., ANd Lux, R. D. 2001. Mafic intrusions on Campobello Island: implications for New Brunswick-Maine correlations. Atlantic Geology, 37, pp. 17-40.

Miller, B.V., Barr, S. M., Fyffe, L.R., and White, C.E. 2000. New U-Pb ages from southern New Brunswick: preliminary results. In Current Research 1999. Edited by B.M.W. Carroll. New Brunswick Department of Natural Resources and Energy,
Minerals and Energy Division, Mineral Resource Report 20004, pp. 39-50.

Nowlan, G.S., McCracken, A.D., and McLeod, M.J. 1997. Tectonic and paleogeographic significance of Late Ordovician conodonts in the Canadian Appalachians. Canadian Journal of Earth Sciences, 34, pp. 1521-1537.

PickeriLl, R.K. 1976. Significance of a new fossil locality containing a Salopina community in the Waweig Formation (Silurian-uppermost Ludlow/Pridoli) of southwest New Brunswick. Canadian Journal of Earth Sciences, 13, pp. 1328-1331.

Pickerill, R.K. ANd Pajari, G.E., Jr. 1976. The Eastport Formation (Lower Devonian) in the northern Passamaquoddy Bay area, southwest New Brunswick. Canadian Journal of Earth Sciences, 13, pp. 266-270.

Pickerill, R.K., Pajari, G.E., and Dickson, W.L. 1978. Geology of the Lower Devonian rocks of Passamaquoddy Bay, southwest New Brunswick. In Guidebook for Field Trips in Southeastern Maine and Southwestern New Brunswick. Edited by A. Ludman. 70th Annual Meeting, New England Intercollegiate Geological Conference, pp. 38-56.

Ratajeski, K., Glazner, A.F., AND Miller, B.V. 2001. Geology and geochemistry of mafic to felsic plutonic rocks in the Cretaceous intrusive suite of Yosemite Valley, California, Geological Society of America Bulletin, 113, pp. 1486-1502.

RUITENBERG, A.A. 1967. Stratigraphy, structure and metallization, Piskahegan-Rolling Dam area, northern Appalachians, New Brunswick, Canada. Leidse Geologische Mededelingen, 40, pp. 79-120.

Ruitenberg, A.A. 1968. Geology and mineral deposits, Passamaquoddy Bay area. New Brunswick Department of Natural Resources, Mineral Resources Branch, Report of Investigation 7, $47 \mathrm{p}$.

Tucker, R.D. and McKerrow, W.S. 1995. Early Paleozoic chronology: a review in light of new U-Pb zircon ages from Newfoundland and Britain. Canadian Journal of Earth Sciences, 32, pp. 368-379.

VAN Wagoner, N.A., McNeIL, W., AND FAy, V.K. 1988. Early Devonian bimodal volcanic rocks of southwestern New Brunswick: petrography, stratigraphy, and depositional setting. Maritime Sediments and Atlantic Geology, 24, pp. 301-319.

Van Wagoner, N.A., Dadd, K.A., Baldwin, D.K., AND McNeIL, W. 1994. Physical volcanology, stratigraphy, and depositional setting of the Middle Paleozoic volcanic and sedimentary rocks of Passamaquoddy Bay, southwestern New Brunswick. Geological Survey of Canada, Paper 91-14, 46 p.

Watkins, R. ANd Воucot, A.J. 1975. Evolution of Silurian brachiopod communities along the southeastern coast of Acadia. Geological Society of America, Bulletin, 86, pp. 243-254.

Editorial responsibility: Sandra M. Barr 